\title{
FOOT-OF-THE-WAVE ANALYSIS OF THE ELECTROCATALYTIC DECHLORINATION OF HEXACHLOROETHANE USING COBALOXIMES
}

\author{
SEBASTIÁN PIZARRO ${ }^{I^{*}}$, MICHAEL ARAYA ${ }^{3}$, FRANCISCO GAJARDO ${ }^{2}$, DARLY CONCHA $^{2}$ AND \\ ALVARO DELGADILLO ${ }^{2 *}$

\begin{abstract}
${ }^{I}$ Instituto de Investigación Multidisciplinario en Ciencias y Tecnologías, Universidad de La Serena, Casilla 599, Benavente 980; La Serena, Chile. ${ }^{2}$ Departamento de Química, Facultad de Ciencias, Universidad de La Serena, Casilla 599, Benavente 980; La Serena, Chile. ${ }_{3}^{3}$ Centro de Investigación y desarrollo tecnológico en Algas (CIDTA), Facultad de Ciencias del Mar, Universidad Católica del Norte, Larrondo 1281, Coquimbo, Chile.
\end{abstract}

\begin{abstract}
In this work the electrochemical degradation of polychlorinated compounds using $\mathrm{Co}(\mathrm{dmgH})_{2} \mathrm{Cl}(\mathrm{py}), \mathrm{Co}(\mathrm{dpgH})_{2} \mathrm{Cl}(\mathrm{py}), \quad \mathrm{Co}(\mathrm{chgH})_{2} \mathrm{Cl}(\mathrm{py})$ and $\mathrm{Co}(\mathrm{dbegH})_{2} \mathrm{Cl}(\mathrm{py})$ (where $\mathrm{dmgH}$ is dimethylglyoximato, $\mathrm{dpgH}$ is diphenylglyoximato, chgH is 1,2-cyclohexanedionedioximato and dbegH is 4,4'-((1E,2E)-1,2-bis(hydroxyimino)ethane-1,2-diyl)dibenzoate) is described. The degradation was studied using cyclic voltammetry by monitoring current changes in the zone near to the Co(II/I) half wave potential as the concentration of the organochloride in the electrochemical cell is increased. Hexachloroethane (HCA) was used as organohalide substrate, while gamma-hexachlorocyclohexane (lindane), 1,2-dichloroethane, and 1,1,1-trichloroethane were used for comparative studies. The major dechlorination product of HCA, detected through head space GC-MS experiments after bulk electrolysis, was tetrachlorethylene. The rate constants of the dechlorination processes were estimated using the foot-of-the-wave analysis (FOWA), the values obtained were $1.10 \times 10^{5}, 2.59 \times 10^{4}, 4.91 \times 10^{4}$ and $1.83 \times 10^{4}$ for $\mathrm{Co}(\mathrm{dmgH})_{2} \mathrm{Cl}(\mathrm{py}), \mathrm{Co}(\mathrm{dpgH})_{2} \mathrm{Cl}(\mathrm{py}), \mathrm{Co}(\mathrm{chgH})_{2} \mathrm{Cl}\left(\right.$ py) and $\mathrm{Co}(\mathrm{dpegH})_{2} \mathrm{Cl}($ py) respectively.
\end{abstract}

Keywords: Cobaloxime; cyclic voltammetry; organochlorines; catalysis.

\section{INTRODUCTION}

The compounds that have multiple chlorine atoms in their structure could be dangerous for human health ${ }^{1,2}$. Prolonged exposure to these type of compounds can generate various problems such as central nervous system disorders ${ }^{3}$, cardiovascular diseases ${ }^{4}$, depression of the immune system ${ }^{5}$ or $_{\text {cancer }}{ }^{6-8}$.

They also could be harmful for the environment, and despite the restrictions that are applied for their use, they are widely employed in agriculture as pesticides or herbicides, becoming ubiquitous pollutants in soils and waters ${ }^{9}$.

The cleavage of the $\mathrm{C}-\mathrm{Cl}$ bonds could lead to safer products, e.g. vinyl chloride, a known carcinogen, produces non-toxic ethylene after their dechlorination ${ }^{10,11}$. In this context, different strategies have been explored to cleavage carbon-chlorine bonds such as biodegradation ${ }^{12}$, the use of zero valent iron $^{13}$ and the catalytic reduction with molecular catalysts ${ }^{14-16}$. The latter is the most interesting because the catalysts can be tailored by introducing structural modifications in order to improve the catalytic activity in the degradation of specific pollutants.

Cobaloximes ${ }^{17}$ are a class of molecular catalysts based on cobalt and glyoxime ligands which are capable to participate in reductive dechlorination reactions since they are strong nucleophiles upon reaching the $\operatorname{Co}(\mathrm{I})$ state. The electrochemical reduction potential of the $\mathrm{Co}(\mathrm{II} / \mathrm{I})$ couple can be tuned by making structural modifications to the glyoxime ligands, generally introducing electron withdrawal groups on the ligands will displace the $\mathrm{Co}(\mathrm{II} / \mathrm{I})$ potentials towards more positive values. In literature it has been reported that these changes could result in a decrease of the activity for some catalytic processes ${ }^{18-22}$, nevertheless we have recently reported the use of cobaloximes for the catalytic reduction of hexachloroethane to tetrachloroethene employing a series of cobaloximes where the $\mathrm{Co}(\mathrm{II} / \mathrm{I})$ reduction potential was tuned in the -0.91 to $0.69 \mathrm{~V}$ vs $\mathrm{Ag} / \mathrm{AgCl}$ range by varying the substituents on the glyoxime ligand, and found little differences in observed rate constant using the total catalysis model $^{23}$.

This model could not be the best to describe the kinetics of these systems, therefore in this work we will use the foot-of-the-wave (FOWA) model to analyze the electrochemical behavior of a family of cobaloxime complexes as catalysts in the dechlorination of several organochlorine compounds.

\section{EXPERIMENTAL}

\subsection{Materials and measurements}

All the chemicals were commercially available and used as received. $\mathrm{Co}(\mathrm{dmgH})_{2} \mathrm{Cl}(\mathrm{py})^{24}, \quad \mathrm{Co}(\mathrm{dpgH})_{2} \mathrm{Cl}(\mathrm{py})^{25}, \quad \mathrm{Co}(\mathrm{chgH})_{2} \mathrm{Cl}(\mathrm{py})^{26} \quad$ and $\mathrm{Co}(\mathrm{dbegH})_{2} \mathrm{Cl}(\mathrm{py})^{27}$ were synthesized according to procedures reported in literature. The organochlorine compounds employed for the catalytic degradation experiments were HCA, 1,2-dichloroethane and 1,1,1trichloroethane.

\subsection{Electrochemistry}

Cyclic voltammetry experiments were conducted on a Princeton Applied Research PG 580 potentiostat/galvanostat using a three-electrode single compartment cell including a glassy carbon working electrode, a Pt wire auxiliary electrode, and an $\mathrm{Ag} / \mathrm{AgCl}$ reference electrode. Tetrabutylammonium hexafluorophosphate $\left[\mathrm{NBu}_{4}\right]\left[\mathrm{PF}_{6}\right]$ was used as the supporting electrolyte $(0.1$ $\left.\mathrm{mol} \mathrm{L}^{-1}\right)$. For all measurements, samples were degassed by purging with nitrogen.

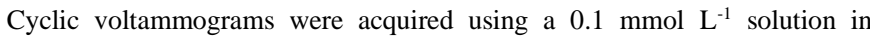
cobaloxime and adding small aliquots of the organochlorine compounds in order to increase their concentration from 0.1 to $14 \mathrm{mmol} \mathrm{L}^{-1}$.

\subsection{Bulk electrolysis experiments}

A homemade electrolysis cell suited with a carbon mesh as the working electrode, platinum wire as the auxiliary electrode and an $\mathrm{Ag} / \mathrm{AgCl}$ reference electrode was used. In a typical experiment $10 \mathrm{~mL}$ an acetonitrile $0.1 \mathrm{M}$ $\left[\mathrm{NBu}_{4}\right]\left[\mathrm{PF}_{6}\right]$ solution containing $1.4 \mathrm{mmol} \mathrm{L}^{-1}$ of the catalyst and $14 \mathrm{mmol} \mathrm{L}^{-1}$ of the organochlorine was purged with $\mathrm{N}_{2}$, then was subjected to electrolysis for a period of 60 minutes at $-0.95 \mathrm{~V}$.

\subsection{Headspace experiments}

Headspace combined with gas chromatography-mass spectrometry (GC-MS) was used to analyze the volatile organic compounds (VOCs) after the bulk electrolysis experiments. The sample vials containing $200 \mu \mathrm{L}$ of the post-reaction solution were oven heated for $20 \mathrm{~min}$ at $100{ }^{\circ} \mathrm{C}$, then $5 \mu \mathrm{L}$ of the headspace were injected into the port of an Agilent Technologies GC-MS 5890A with a HP-5ms column $(30 \mathrm{~m} \times 0.25 \mathrm{~mm} \times 0.25 \mu \mathrm{m})$. The injection port was in a split mode $(1: 10)$

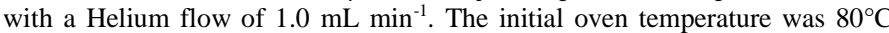
ramped at $10{ }^{\circ} \mathrm{C} \mathrm{min}^{-1}$ to $200^{\circ} \mathrm{C}$. The temperature of MS Quad $120^{\circ} \mathrm{C}$ and 230 for the MS Source. The scan parameters were 50 to $300 \mathrm{~m} / \mathrm{z}$.

\section{RESULTS AND DISCUSSION}

The structures of all the complexes used in this study are presented in Fig. 1. The cyclic voltammograms of these compounds are shown in Fig. S1 in the supporting information. They show an irreversible process assigned to the reduction of the pair $\mathrm{Co}$ (III)/Co(II) and a reversible reduction process assigned to the reduction of the pair $\mathrm{Co}$ (II)/Co(I), the reduction potential values are presented in table 1, this behavior is consistent with the reported in the literature $^{28}$. 


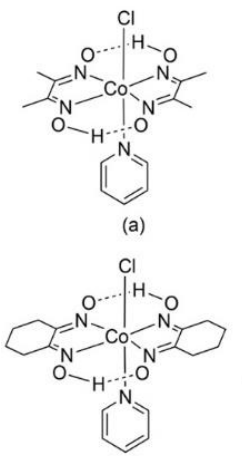

(c)
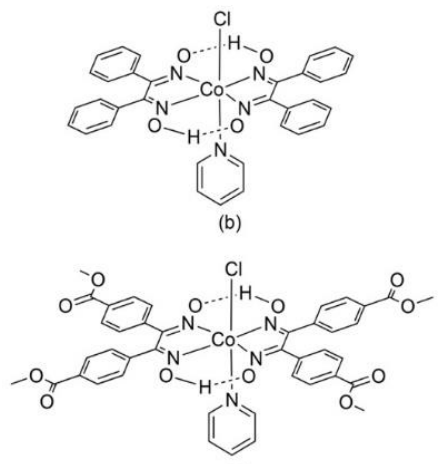

(d)
Figure 1. Structures of the cobaloximes used in this study: (a) $\mathrm{Co}(\mathrm{dmgH})_{2} \mathrm{Cl}(\mathrm{py}) ; \quad$ (b) $\mathrm{Co}(\mathrm{dpgH})_{2} \mathrm{Cl}(\mathrm{py}) ; \quad$ (c) $\mathrm{Co}(\mathrm{chgH})_{2} \mathrm{Cl}(\mathrm{py})$ and (d) $\mathrm{Co}(\mathrm{dbegH})_{2} \mathrm{Cl}(\mathrm{py})$.

In cyclic voltammetry experiments, the addition of HCA to a cobaloxime solution led to the appearance of a considerable current increase in the zone near the $\mathrm{Co}(\mathrm{II} / \mathrm{I})$. This behavior is exemplified in Fig. 2a which shows the change in the cyclic voltammograms of $\left[\mathrm{Co}(\mathrm{dbegH})_{2} \mathrm{Cl}(\mathrm{py})\right]$ in $\mathrm{DMF} 0.1 \mathrm{~mol} \mathrm{~L}^{-1}$ $\left[\mathrm{NBu}_{4}\right]\left[\mathrm{PF}_{6}\right]$ at a scan rate of $100 \mathrm{mVs}^{-1}$ after the addition of $0.3-1.4 \mathrm{mmol} \mathrm{L}^{-1}$ of $\mathrm{HCA}$. The electrochemical response of $\mathrm{Co}(\mathrm{dmgH})_{2} \mathrm{Cl}(\mathrm{py}), \mathrm{Co}(\mathrm{dpgH})_{2} \mathrm{Cl}(\mathrm{py})$ and $\mathrm{Co}(\mathrm{chgH})_{2} \mathrm{Cl}($ py) versus HCA are shown in Fig. S2, S3 and S4 in the supporting information. These changes in the electrochemical response are indicative of the catalytic activity of the complex in the dechlorination of the substrate.

a)

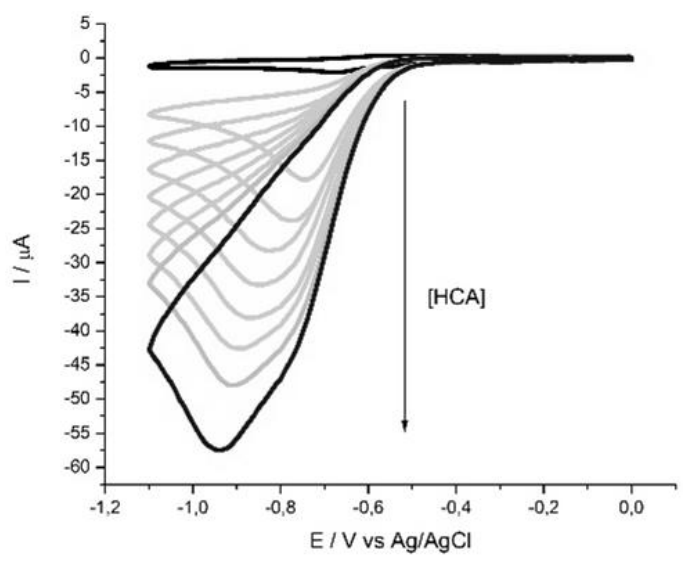

b)

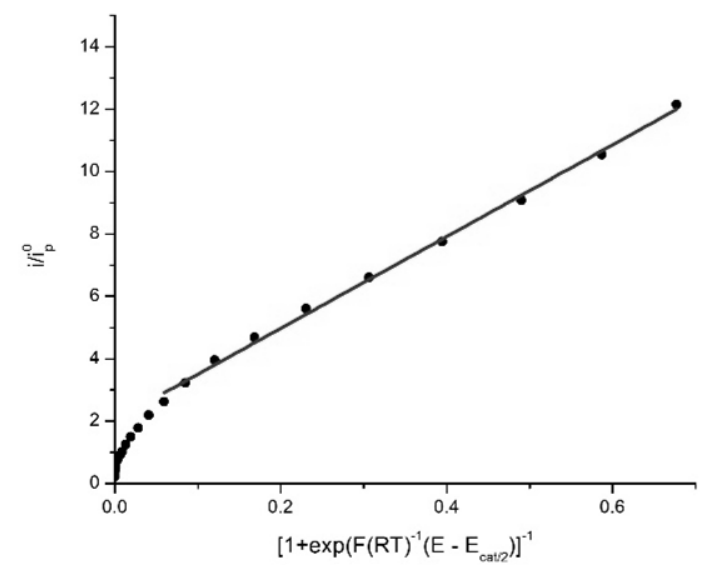

Figure 2. a) Cyclic voltammogram of $\mathrm{Co}(\mathrm{dbegH})_{2} \mathrm{Cl}\left(\right.$ py) $0.100 \mathrm{mmol} \mathrm{L}^{-1}$ in DMF $0.1 \mathrm{~mol} \mathrm{~L}^{-1}\left[\mathrm{NBu}_{4}\right]\left[\mathrm{PF}_{6}\right]$. Registered at a scan rate of $100 \mathrm{mV} \mathrm{s}^{-1}$ (black line) in the presence of 0.3 to $1.4 \mathrm{mmol} \mathrm{L}^{-1}$ of HCA (gray line). b) FOWA plot derived from cyclic voltammetry analysis, slope $=14.7 R^{2}=0.99707$.

To identify the HCA dichlorination reaction products, gas chromatography (GC-MS) experiments were carried out sampling the headspace of the respective cobaloxime/chlorinated substrate solution (molar ratio 1:10) after 90 minutes of electrolysis (Fig. 3), found tetrachloroethene as the majority product.

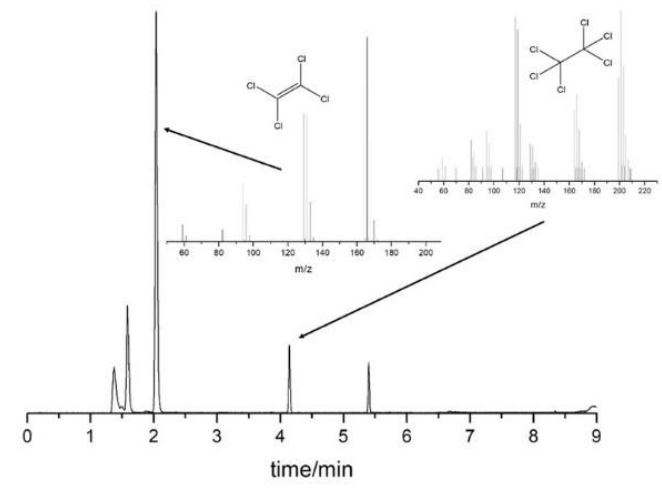

Figure 3. GC-MS electrolysis between $\mathrm{Co}(\mathrm{dbegH})_{2} \mathrm{Cl}(\mathrm{py})$ and $\mathrm{HCA}$ recorded in $\mathrm{ACN}$.

A possible mechanism of the dechlorination process could begin with the sequential reduction of the cobalt center from the oxidation states III to I. This process has been described previously and involves an intermediate when the chloride ligand is lost. When the cobaloxime reaches the Co(I) state reacts with the organochlorine substrate causing the cleavage of the $\mathrm{C}-\mathrm{Cl}$ bond, releasing the reduced organochlorine and the oxidized catalyst, probably by an inner-sphere mechanism. Equations 1-5 describes this mechanism using HCA as a substrate. The glyoxime and pyridine ligands have been omitted for simplicity.

$$
\begin{aligned}
& \mathrm{Co}(\mathrm{III}) \mathrm{Cl}+\mathrm{e}^{-} \rightarrow \mathrm{Co}(\mathrm{II}) \mathrm{Cl}^{-} \\
& \mathrm{Co}(\mathrm{II}) \mathrm{Cl}^{-} \rightarrow \mathrm{Co}(\mathrm{II})+\mathrm{Cl}^{-} \\
& \mathrm{Co}(\mathrm{II})+\mathrm{e}^{-} \rightarrow \mathrm{Co}(\mathrm{I})^{-} \\
& \mathrm{Co}(\mathrm{I})^{-}+\mathrm{Cl}_{3} \mathrm{C}-\mathrm{CCl}_{3} \rightarrow \mathrm{Co}(\mathrm{III}) \mathrm{Cl}+\mathrm{Cl}_{3} \mathrm{C}-\mathrm{CCl}_{2}{ }^{-} \\
& \mathrm{Cl}_{3} \mathrm{C}-\mathrm{CCl}_{2}{ }^{-} \rightarrow \mathrm{Cl}_{2} \mathrm{C}=\mathrm{CCl}_{2}+\mathrm{Cl}^{-}
\end{aligned}
$$

The kinetics of the process can be studied by estimating the observed rate constant $\left(\mathrm{k}_{\mathrm{obs}}\right)$ from the relation between the cathodic current and the square root of the organochloride concentration, as presented in equation 1 :

$$
i_{c}=n F A[\text { Cobaloxime }] D^{1 / 2} k_{o b s}{ }^{1 / 2}[R X]^{1 / 2}
$$

Where $n$ is the number of electrons for the reaction ( $\mathrm{n}=2)$, F is Faraday constant $\left(96485 \mathrm{C} \mathrm{mol}^{-1}\right), A$ is the area of the electrode surface $\left(0.072 \mathrm{~cm}^{2}\right), D$ is the diffusion coefficient $\left(\mathrm{cm}^{2} \mathrm{~s}^{-1}\right)$ and $k$ is the apparent rate constant for the reaction $\left(\mathrm{L} \mathrm{mol} \mathrm{s}^{1} \mathrm{~s}^{-1}\right.$ ). Under pure kinetic conditions, the cyclic voltammogram should adopt an S-shaped response independent of the scan rate ${ }^{29}$.

Although equation 1 allows obtaining the value of $\mathrm{k}_{\mathrm{obs}}$ without complications, the catalytic voltammograms moved away from the ideal S-shape behavior, which could be attributed to side phenomena such as substrate consumption or catalyst inhibition ${ }^{30,31}$.

In order to minimize the effect of these competitive secondary phenomena from the kinetic analysis we used the foot-of-the-wave analysis (FOWA) methodology developed by Saveant ${ }^{32}$ in which the observed rate constant is estimated by modeling the cyclic voltammogram near the foot of the wave where these factors play a small role and its shape is dominated by the catalytic reaction ${ }^{33}$.

The FOWA analysis considers that the process occurs in multiple stages and all electron transfers occur at the electrode, the expression of the current is given by equation 2 :

$$
\frac{i_{c a t}}{i_{p}^{0}}=\frac{2.24 \sqrt{\frac{R T}{F v} k_{o b s}}}{1+\exp \left(\frac{F}{R T}\left(E-E_{c a t / 2}\right)\right)}\left(\frac{n_{c a t}}{n_{p}^{3 / 2}}\right)
$$

where $k_{\text {obs }}$ is the observed rate constant, $i_{\text {cat }}$ is the catalytic current $(A), i_{p}$ catalyst current in the absence of substrate (A), E is the applied potential (V), $\mathrm{E}_{\mathrm{cat} / 2}$ is the half-wave potential is defined as the point at which the homogeneous catalytic wave reaches half of its maximum current $(\mathrm{V}), \mathrm{n}_{\text {cat }}$ number electrons transferred $(n=2), n_{p}$ number of electrons of the catalyst $(n=1), v$ is the scan rate $\left(\mathrm{Vs}^{-1}\right), \mathrm{R}$ is the gas constant $\left(\mathrm{J} \mathrm{K}^{-1} \mathrm{~mol}^{-1}\right)$, and T is the temperature $(\mathrm{K})$. 
From the linear fit of $\mathrm{i} / \mathrm{i}_{\mathrm{p}}{ }^{0}$ as a function of $\left[1+\exp \left(\mathrm{F}(\mathrm{RT})^{-1}\left(\mathrm{E}-\mathrm{E}_{\mathrm{cat} / 2}\right)\right)\right]^{-1}$ a value of $\mathrm{k}_{\mathrm{obs}}$ can be extracted. The FOWA plot derived from the analysis of the cyclic voltammogram is presented in Fig. $2 \mathrm{~b}$ and in the supporting information for the other cobaloximes.

The rate constant of the catalyst in the dechlorination processes, $\mathrm{k}_{\mathrm{cat}}$, can be estimated by plotting $\mathrm{k}_{\mathrm{obs}}$ obtained from the FOWA analysis versus the concentration of the substrate [mol L-1] considering a first-order dependence for both the catalyst and the organochlorine. The expression of this relationship is represented by equation 3 :

$$
k_{o b s}=k_{c a t}[R X]
$$

Fig. 4 show the linear fit of $\mathrm{k}_{\text {obs }}$ of each cobaloxime versus the concentrations of HCA. Table 1 compiles the observed rate constants obtained by the FOWA analysis.

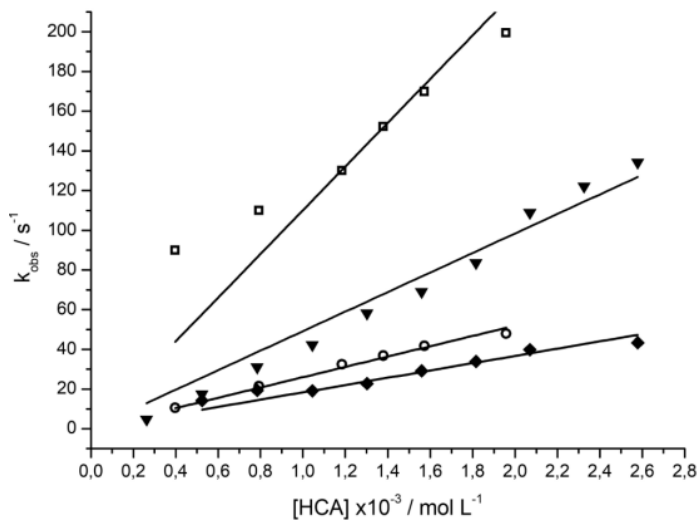

Figure 4. Dependence of the $\mathrm{k}_{\mathrm{obs}}\left(\mathrm{s}^{-1}\right)$ vs the concentration of HCA $\left(\mathrm{mol} \mathrm{L}^{-1}\right)$, the data were adjusted to $\mathrm{k}_{\mathrm{obs}}=\mathrm{m}[\mathrm{HCA}]+0: \mathrm{Co}(\mathrm{dmgH})_{2} \mathrm{Cl}(\mathrm{py})$ : slope $=110088$ $\mathrm{R}^{2}=0.97283$ (square); $\mathrm{Co}(\operatorname{chgH})_{2} \mathrm{Cl}(\mathrm{py})$ : slope $=49190 \mathrm{R}^{2}=0,99001$ (triangle); $\mathrm{Co}(\mathrm{dpgH})_{2} \mathrm{Cl}($ py $)$ : slope $=25979 \mathrm{R}^{2}=0.99756($ circle $) ; \mathrm{Co}(\mathrm{dbegH})_{2} \mathrm{Cl}($ py) slope $=18348 \mathrm{R}^{2}=0.98918$ (diamond)

It can be seen that the value of the $\mathrm{k}_{\text {cat }}$ obtained by the FOWA analysis decreases when the potential of the redox pair Co (II/I) becomes more positive. This is congruent with the behavior reported for catalytic hydrogen evolution systems catalyzed by cobaloximes, where the presence of electron-withdrawing groups in the glyoxime ligand decreases the basicity of the cobalt center when it is reduced to Co (I), influencing its nucleophic character.

Table 1. Reduction potentials and rate constants of the cobaloximes used in this study.

\begin{tabular}{|c|c|c|}
\hline & $\begin{array}{c}\mathrm{E}_{1 / 2}(\mathrm{~V}) \\
\mathrm{Co}(\mathrm{II} / \mathrm{I})\end{array}$ & $\mathrm{k}_{\text {cat }}\left(\mathrm{Lmol}^{-1} \mathrm{~s}^{-1}\right)$ FOWA analysis \\
\hline $\mathrm{Co}(\mathrm{dmgH})_{2} \mathrm{Cl}(\mathrm{py})$ & -0.91 & $1.10 \times 10^{5}$ \\
\hline $\mathrm{Co}(\mathrm{dpgH})_{2} \mathrm{Cl}(\mathrm{py})$ & -0.69 & $2.59 \times 10^{4}$ \\
\hline $\mathrm{Co}(\mathrm{chgH})_{2} \mathrm{Cl}(\mathrm{py})$ & -1.01 & $4.91 \times 10^{4}$ \\
\hline $\mathrm{Co}(\mathrm{dbegH})_{2} \mathrm{Cl}(\mathrm{py})$ & $-0,62$ & $1.83 \times 10^{4}$ \\
\hline
\end{tabular}

Fig. 5 shows the overlay plot of $\left[\mathrm{Co}(\mathrm{dbegH})_{2} \mathrm{Cl}(\mathrm{py})\right]$ cyclic voltammograms when 1,1,1-trichloroethane, 1,2-dichloroethane, lindane and HCA, are added to the cobaloxime solution. This figure shows a difference in the catalytic current even at the same substrate concentration. For lindane, the catalytic currents were lower compared to $\mathrm{HCA}^{27}$, and almost inexistent for 1,1,1-trichloroethane, 1,2dichloroethane.

These last substrates have the same amount of carbons as HCA, but different number and position of the chlorine atoms. The analysis of the data suggests there is a relationship between the structure of the substrate and its ability to participate in reductive dechlorination reactions. This behavior has also been previously reported for cobalt porphyrins, which can only reduce local dihalides when they are in an antiperiplanar configuration ${ }^{34}$. Probably this structural restriction also affects to the reaction of organohalides with cobaloximes.

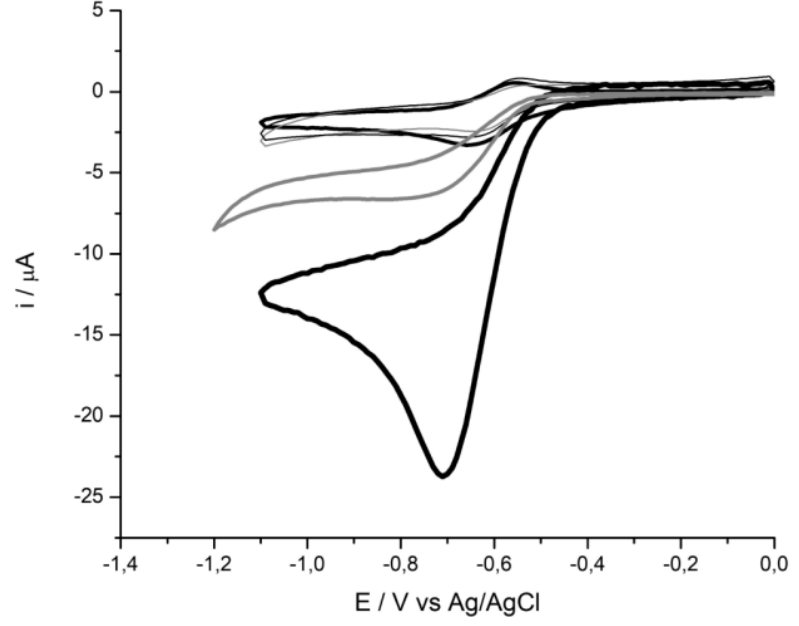

Figure 5. Cyclic voltammogram of $\mathrm{Co}(\mathrm{dbegH})_{2} \mathrm{Cl}(\mathrm{py}) 0.1 \mathrm{mmol} \mathrm{L}^{-1}$ in $\mathrm{DMF}$ $0.1 \mathrm{~mol} \mathrm{~L}^{-1}\left[\mathrm{NBu}_{4}\right]\left[\mathrm{PF}_{6}\right]$. Registered at a scan rate of $100 \mathrm{mV} \mathrm{s}^{-1}$ (black line) in the presence of $1.0 \mathrm{mmol} \mathrm{L}^{-1}$ of 1,1,1-trichloroethane (black line), 1,2dichloroethane (gray line), lindane (gray bold line) and HCA (black bold line).

\section{CONCLUSION}

The catalytic dehalogenation of HCA using cobaloximes can be described using the FOWA analysis, which indicates a relationship between the activity of the catalyst, the $\mathrm{Co}(\mathrm{II} / \mathrm{I})$ reduction potential and the structure of the glyoxime ligands.

Cobaloximes, nevertheless, apparently are efficient dehalogenation catalysts only of organochloride compounds which present vicinal chlorides.

\section{ACKNOWLEDGMENTS}

The authors acknowledge DIULS PI 17161; DIULS PR 17161, Plan de Mejoramiento Institucional en Eficiencia Energética y Sustentabilidad Ambiental ULS-1401.

\section{REFERENCES}

1. Pleština, R. PESTICIDES AND HERBICIDES | Types of Pesticide. in Encyclopedia of Food Sciences and Nutrition 90, 4473-4483 (Elsevier, 2003).

2. Sparling, D. W. Organochlorine Pesticides. in Ecotoxicology Essentials 69 107 (Elsevier, 2016). doi:10.1016/B978-0-12-801947-4.00004-4.

3. Coakley, J., Bridgen, P., Bates, M. N., Douwes, J. \& t Mannetje, A Chlorinated persistent organic pollutants in serum of New Zealand adults, 2011-2013. Sci. Total Environ. 615, 624-631 (2018)

4. Kim, S. A., Kim, K. S., Lee, Y. M., Jacobs, D. R. \& Lee, D. H. Associations of organochlorine pesticides and polychlorinated biphenyls with total, cardiovascular, and cancer mortality in elders with differing fat mass. Environ. Res. 138, 1-7 (2015).

5. Crinnion, W. J. Chlorinated pesticides: Threats to health and importance of detection. Altern. Med. Rev. 14, 347-359 (2009).

6. Corsini, E., Liesivuori, J., Vergieva, T., Van Loveren, H. \& Colosio, C. Effects of pesticide exposure on the human immune system. Hum. Exp. Toxicol. 27, 671-80 (2008)

7. Dich, J., Zahm, S. H., Hanberg, A. \& Adami, H. O. Pesticides and cancer. Cancer Causes Control 8, 420-443 (1997).

8. Taiwo, A. M. A review of environmental and health effects of organochlorine pesticide residues in Africa. Chemosphere 220, 1126-1140 (2019).

9. Zhu, W. et al. A New Strategy towards Efficient and Recyclable CarbonChloride Bond Cleavage of Environmentally Harmful Organochlorides through Electrochemical Catalysis in Non-aqueous Media. ChemistrySelect 2, 645-649 (2017).

10. Fritsch, J. M. \& McNeill, K. Aqueous reductive dechlorination of chlorinated ethylenes with tetrakis(4-carboxyphenyl)porphyrin cobalt. Inorg. Chem. 44, 4852-4861 (2005)

11. WHO. IARC MONOGRAPHS ON THE EVALUATION OF CARCINOGENIC RISKS TO HUMANS. IARC, International Agency for Research on Cancer 79, (2001).

12. Aulenta, F., Majone, M., Verbo, P. \& Tandoi, V. Complete dechlorination of tetrachloroethene to ethene in presence of methanogenesis and acetogenesis by an anaerobic sediment microcosm. Biodegradation 13, 411-424 (2002). 
13. Ma, C. \& Wu, Y. Dechlorination of perchloroethylene using zero-valent metal and microbial community. Environ. Geol. 55, 47-54 (2008).

14. Kliegman, S. \& McNeill, K. Dechlorination of chloroethylenes by cob(I)alamin and cobalamin model complexes. Dalt. Trans. 9226, 41914201 (2008).

15. Costentin, C., Robert, M. \& Savéant, J. M. Successive removal of chloride ions from organic polychloride pollutants. Mechanisms of reductive electrochemical elimination in aliphatic gem-polychlorides, $\alpha, \beta$ polychloroalkenes, and $\alpha, \beta$-polychloroalkanes in mildly protic medium. $J$. Am. Chem. Soc. 125, 10729-10739 (2003).

16. Assaf-Anid, N., Hayes, K. F. \& Vogel, T. M. Reduction dechlorination of carbon tetrachloride by cobalamin(II) in the presence of dithiothreitol: mechanistic study, effect of redox potential and $\mathrm{pH}$. Environ. Sci. Technol. 28, 246-252 (1994).

17. Rich, A. E., DeGreeff, A. D. \& McNeill, K. Synthesis of (chlorovinyl)cobaloxime complexes, model complexes of proposed intermediates in the B12-catalyzed dehalogenation of chlorinated ethylenes. Chem. Commun. 2, 234-235 (2002).

18. Bhattacharjee, A. et al. Combined Experimental-Theoretical Characterization of the Hydrido-Cobaloxime [HCo(dmgH)2( $\mathrm{Pn} \mathrm{Bu} 3)]$. Inorg. Chem. 51, 7087-7093 (2012).

19. Kaeffer, N., Chavarot-Kerlidou, M. \& Artero, V. Hydrogen evolution catalyzed by cobalt diimine-dioxime complexes. Acc. Chem. Res. 48, 12861295 (2015).

20. Valdez, C. N., Dempsey, J. L., Brunschwig, B. S., Winkler, J. R. \& Gray, H. B. Catalytic hydrogen evolution from a covalently linked dicobaloxime. Proc. Natl. Acad. Sci. 109, 15589-15593 (2012).

21. Lawrence, M. A. W. et al. Computational, electrochemical, and spectroscopic studies of two mononuclear cobaloximes: the influence of an axial pyridine and solvent on the redox behaviour and evidence for pyridine coordination to cobalt(I) and cobalt(II) metal centres. Dalt. Trans. 45, 10326-10342 (2016).

22. Losse, S., Vos, J. G. \& Rau, S. Catalytic hydrogen production at cobalt centres. Coord. Chem. Rev. 254, 2492-2504 (2010).

23. Pizarro, S., Araya, M. \& Delgadillo, A. Hexachloroethane reduction catalyzed by cobaloximes. Effect of the substituents on the equatorial ligands. Polyhedron 141, 94-99 (2018).
24. Fan, W. Y., Tan, Z. Bin \& Koh, J. I. Proton reduction using cobalt glyoximes with isothiocyanate and aniline axial ligands. Polyhedron 96, 38-43 (2015).

25. Concepción, S., Aguiló, M., Solans, X. \& Font-Altaba, M. Synthesis and Structure of Chloro ( ligand ) bis ( diphenylglyoximato ) cobalt ( Complexes. Inorganica Chim. Acta 127, 153-159 (1987).

26. Xin, Z., Deyan, H., Yizhi, L. \& Huilan, C. Structure and thermal decomposition studies on alkylcobaloxime B 12 model compounds with 1,2cyclohexanedione dioxime as equatorial ligand. Inorganica Chim. Acta 359, 1121-1128 (2006).

27. Pizarro, S., Gallardo, M., Gajardo, F. \& Delgadillo, A. Electrochemical reduction of lindane using a cobaloxime containing electron-withdrawing groups. Inorg. Chem. Commun. 99, 164-166 (2019).

28. Panagiotopoulos, A., Ladomenou, K., Sun, D., Artero, V. \& Coutsolelos, A. G. Photochemical hydrogen production and cobaloximes: the influence of the cobalt axial N-ligand on the system stability. Dalt. Trans. 45, 6732-6738 (2016).

29. Lee, K. J., Elgrishi, N., Kandemir, B. \& Dempsey, J. L. Electrochemical and spectroscopic methods for evaluating molecular electrocatalysts. Nat. Rev. Chem. 1, 0039 (2017).

30. Costentin, C., Drouet, S., Robert, M. \& Savéant, J. M. Turnover numbers, turnover frequencies, and overpotential in molecular catalysis of electrochemical reactions. Cyclic voltammetry and preparative-scale electrolysis. J. Am. Chem. Soc. 134, 11235-11242 (2012).

31. Costentin, C. \& Savéant, J.-M. Multielectron, Multistep Molecular Catalysis of Electrochemical Reactions: Benchmarking of Homogeneous Catalysts. ChemElectroChem 1, 1226-1236 (2014).

32. Costentin, C. \& Savéant, J.-M. Multielectron, Multistep Molecular Catalysis of Electrochemical Reactions: Benchmarking of Homogeneous Catalysts. ChemElectroChem 1, 1226-1236 (2014).

33. Elgrishi, N., Chambers, M. B. \& Fontecave, M. Turning it off! Disfavouring hydrogen evolution to enhance selectivity for $\mathrm{CO}$ production during homogeneous $\mathrm{CO}_{2}$ reduction by cobalt-terpyridine complexes. Chem. Sci. 6 , 2522-2531 (2015).

34. Costentin, C. \& Savéant, J. M. Homogeneous Molecular Catalysis of Electrochemical Reactions: Catalyst Benchmarking and Optimization Strategies. J. Am. Chem. Soc. 139, 8245-8250 (2017). 